\title{
Aleurocanthus Spiniferus (Quaintance) (Orange Spiny Whitefly, Osw) (Hemiptera, Aleyrodidae) Invaded South of Italy
}

Ahmed EL KENAWY ${ }^{1}$, Raul BAETAN ${ }^{2}$ Isabella CORRADO ${ }^{1}$, Daniele CORNARA ${ }^{1}$, Ion OLTEAN ${ }^{2}$ Francesco PORCELLI ${ }^{1 *}$

${ }^{1}$ DiSSPA Sez Entomologia e Zoologia, UNIBA Aldo Moro, Bari, Italy

${ }^{2}$ Universitatea de Stiinte Agricole si Medicina Veterinara - Cluj-Napoca,Romania

* corresponding author: francesco.porcelli@uniba.it

Bulletin USAMV series Agriculture 72(1)/2015

Print ISSN 1843-5246; Electronic ISSN 1843-5386

DOI 10.15835/buasvmcn-agr: 11148

\begin{abstract}
Introduction: Aleurocanthus spiniferus (Quaintance) is one further alien invasive pest that have been invading the south of Italy. From the EPPO first report of the presence of A. spiniferus, in April 2008, Puglia was invaded northward by this polyphagous whitefly and new territories were infested more or less severely.Aims: This poster refers about recently occupied areas detailing local and urban outbreaks and population density per host plant species. Materials and Methods: We use direct observation on the field and digital camera-equipped stereoscope and Cryo-SEM on the laboratory for data confirmation and imaging. Results: We detail the invaded areas, confirming the spreading of this pest in almost all the Puglia region. Conclusions: The overall ecological preferences and behaviour of the pest are depicted in view of its control in urban areas.
\end{abstract}

Keywords: Aleurocanthus spiniferus, OSW, Puglia, whitefly.

\section{INTRODUCTION}

Aleurocanthus spiniferus (Quaintance) is one further alien invasive pest that have been invading the south of Italy. From the EPPO first report of the presence of A. spiniferus, in April 2008, Puglia was invaded northward by this polyphagous whitefly and new territories were infested more or less severely.

\section{AIMS}

This poster refers about recently occupied areas detailing local and urban outbreaks and population density per host plant species.

\section{MATERIALS AND METHODS}

We use direct observation on the field and digital camera-equipped stereoscope and Cryo-
SEM on the laboratory for data confirmation and imaging.

\section{RESULTS AND DISCUSSION}

We detail the invaded areas, confirming the spreading of this pest in almost all the Puglia region.By the end of 2009 OSW infested 68 of the 97 municipalities of Lecce district but the intensity of its infestation varied. In 2010 the pest infested 88 municipalities, except Diso, Guagnano, Melendugno, Novoli, Salice Salentino, Squinzano, Trepuzzi, Uggiano la Chiesa and Veglie. In 2011 OSW started to spread into the villages from the Adriatic coast and apparently Melendugno and Diso were not infested by it. In $2011 \mathrm{~A}$. spiniferus was found on a Citrus limon in a private garden 
from San Pancrazio Salentino, a village in the Brindisi district.

\section{CONCLUSIONS}

The overall ecological preferences and behaviour of the pest are depicted in view of its control in urban areas.

\section{REFERENCES}

1. Cioffi M, Cornara D, Corrado I, Jansen MEM , Porcelli F (2013). The status of Aleurocanthus spiniferus from its unwanted introduction in Italy to date. Bulletin of Insectology 66(2):273-281.
2. Pizza M, Porcelli F (1993). Sull'allestimento di preparati microscopici di pupari di aleirodidi (Homoptera). Bollettino della Società Entomologica Italiana 125(1):3-5.

3. Porcelli F (2008). First record of Aleurocanthus spiniferus (Homoptera: Aleyrodidae) in Puglia, Southern Italy. EPPO Bulletin 38(3):516-518.

4. Porcelli F, Convertini S, Garonna AP, Pizza M (2009). Aleurocanthus spiniferus (quaintance,1903) (rhynchota,aleyrodidae), fitofago da quarantena recentemente introdotto in italia. (eds). XXII Congresso Nazionale Italiano di Entomologia Ancona 15-18 Giugno.

5. *** USDA (1974). New United States records - orange spiny whitefly Aleurocanthus spiniferus (Quaintance) Hawaii. Cooperative-Economic-Insect-Report 24(30):585. 